\title{
38. MANTLE HETEROGENEITY IN THE NORTH ATLANTIC: EVIDENCE FROM LEG 49 GEOCHEMISTRY
}

\author{
J.R. Cann, Department of Geology, The University, Newcastle upon Tyne, England \\ J. Tarney, Department of Geological Sciences, The University, Birmingham, England \\ J. Varet, Bureau de Recherches Géologiques et Minières, Orléans, France \\ and \\ D.A. Wood, Laboratoire Petrographie-Volcanologie, Université Paris-Sud, Orsay, France
}

\section{INTRODUCTION}

One of the principal aims of Leg 49 was to investigate variation in the primary geochemistry of ocean-floor lavas in space and time in North Atlantic. This paper sets out to analyze the geochemical results from Part 2 of this volume with this end in view. We first discuss the setting of sites, and then deal with the implications of the Leg 49 results for mantle heterogeneity. We conclude that there is good evidence for marked heterogeneity at different scales in the North Atlantic area, and that the Leg 49 results provide important evidence of the local and regional patterns of variation in composition. This conclusion is elaborated in the following section, where we compare the North Atlantic area as a whole with other parts of the world's oceans, as far as this is possible with our current state of knowledge. It appears that the basalt type labeled MORB, though common in other parts of the oceans, may be rare or absent in the North Atlantic. In addition, we suggest a possible relative chronology of events of mobility for different elements within the mantle.

\section{SETTING OF THE SITES}

When the IPOD program was originally proposed, one of its main objectives was completion of a cross-shaped array of sites in the North Atlantic. This had a north-south arm, designed for looking at variation in geochemistry of lavas erupting now at the mid-ocean ridge crest, and an east-west arm, to give a view of lavas erupted at one segment of the ridge crest through time. This grand design became modified because of insufficient time, lack of site surveys, and changes of plan, but the essence of it has survived, and Leg 49 was important in completing it. Figure 1 shows the sites eventually drilled. At the center of the cross are two sites drilled during Legs 45 and 46, on 10-m.y.-old crust on each side of the ridge axis at $22^{\circ} \mathrm{N}$. The west end of the cross is marked by the holes on 105-m.y.-old crust drilled during Legs 51 through 53. This crust must have formed at the mid-ocean ridge close to $22^{\circ} \mathrm{N}$. Fifteen degrees north of the center of the cross is the FAMOUS area, where extensive surface sampling was performed by dredge and submersible during the FAMOUS project. Here, a subsidiary cross arm was drilled on Leg 37, out to the west in a series of holes where the crust is from 10 to $20 \mathrm{~m}$.y. old. On Leg 49, we drilled one relatively deep and three shallow holes in very young crust close to the segment of the ridge axis between $36^{\circ}$ and $37^{\circ} \mathrm{N}$. These sites are described in full elsewhere in this volume.
North of FAMOUS lie the Azores, and north of here, $9^{\circ}$ north of FAMOUS, is the area on the Mid-Atlantic Ridge at $45^{\circ} \mathrm{N}$ where an extensive Canadian survey of the ridge axis and crestal mountains was made (Aumento et al., 1971). On Leg 49 we drilled two shallow holes in 10-m.y.-old crust west of the ridge crest here. This area is well north of the topographic bulge associated with the Azores, and far to the south of that of Iceland. It should thus not be influenced by whatever processes produce these bulges.

The northernmost sites on the north-south arm of the cross were drilled on Leg 49 at $63^{\circ} \mathrm{N}$, on the Reykjanes Ridge just south of Iceland. These sites were placed partly to form a northern end to the transect, and partly to investigate the persistence in time of a geochemical gradient, discovered by systematic dredging, which runs south along the crest of the Reykjanes Ridge away from Iceland (Schilling, 1973). The three sites here form another subsidiary east-west arm for the cross, with crustal ages of 2.3, 20 and $36 \mathrm{~m} . \mathrm{y}$.

Thus, though the drilling plan could not be completed as originally envisaged, the holes eventually drilled, when taken with the results of dredging and on-shore work in Iceland, give a fairly complete pattern of samples in the North Atlantic, both along the length of the ridge axis, and away from points on the ridge axis, to represent variation in time. Unfortunately, the grid of sites is rather coarse, and in particular we lack a site in the region of the Charlie Gibbs fracture zone at $52^{\circ} \mathrm{N}$ and one near the Kurchatov fracture zone at $41^{\circ} \mathrm{N}$ (Figure 1), where the lava chemistry may be significantly different from the sites we have sampled.

\section{PREVIOUS GEOCHEMICAL WORK}

The early work on the geochemistry of ocean floor basalts suggested that ocean floor basalts form a relatively homogeneous group quite distinct in character from most other basalt types (Engel, Engel, and Havens, 1965; Frey and Haskin, 1964; Gast, 1965; Kay, Hubbard, and Gast, 1970; see references in Cann and Simkin, 1971). Thus, the rare-earth patterns of most basalts from the ocean floor show a characteristic depletion in light rare earths on a Coryell-Masuda chondrite-normalized plot. $\mathrm{K}, \mathrm{Rb}$, and $\mathrm{Ba}$ have very low abundances, and $\mathrm{K} / \mathrm{Rb}$ ratios range up to over 1000 , well outside the values normal for other basalts. Similarly, Nb, Ta, and Th (Cann, 1970; Varet and Treuil, 1973) have abundances in ocean floor basalts as low as one-tenth those in basalts of ocean islands and continental regions. Among major elements, a high $\mathrm{Ca} / \mathrm{Na}$ ratio, an aluminous character, and generally rather low $\mathrm{Ti}$ all 


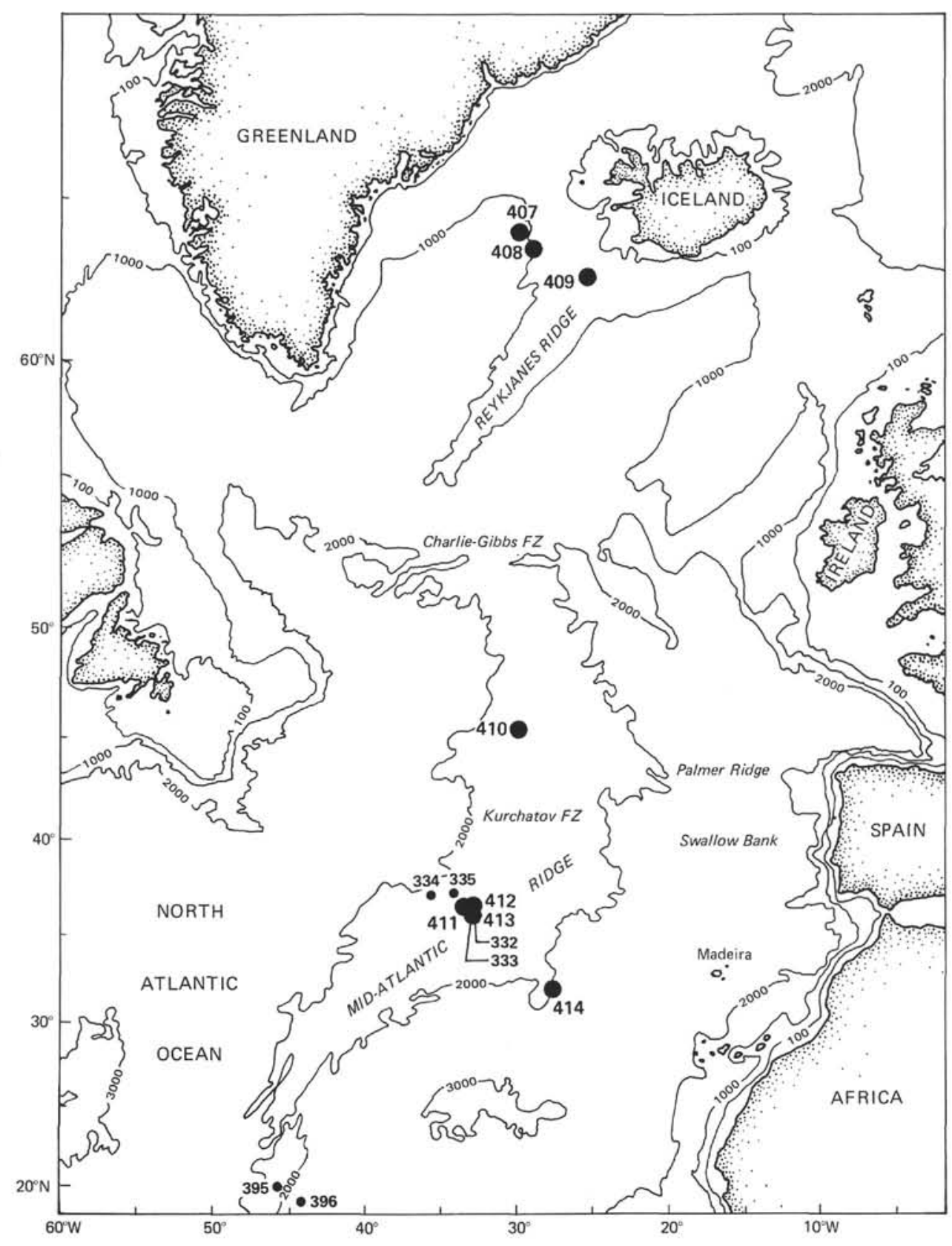

Figure 1. Chart of the North Atlantic showing DSDP sites from Leg 49 and other legs (emphasizing those with substantial basement penetration). Other areas referred to in the text are shown, especially those from which dredged basalts have been analyzed.

reinforced this view of ocean floor basalts as constituting a distinctive and homogeneous type, christened MORB by Hart, Glassley, and Karig (1972). Similar lavas are known from some oceanic island-arc settings (Ewart and Bryan, 1972; Hart, Glassley, and Karig, 1972), though these are generally enriched in $\mathrm{Sr}$ and $\mathrm{Ba}$ relative to the ocean floor basalts, and anyway form only a small proportion of subaerial arc lavas.

The MORB lavas were contrasted particularly with the lavas erupted in Iceland and in other places where spreading centers come above sea level, which compared more closely with the lavas of such ocean islands as Hawaii. This was taken implicitly to represent some difference, either in tectonic environment or in environment of magmagenesis, that resulted both in Iceland reaching above sea level, and in lava being erupted there with composition different from MORB and similar to that of ocean island lava.

Already, however, exceptions to this simple rule were known, most notably at $45^{\circ} \mathrm{N}$ in the Atlantic. Here, an early survey of an arbitrarily chosen piece of ridge crest (Hill, 1960) recovered two dredge hauls; Muir and Tilley (1964, 1966) studied the hauls, and showed that the basalts had a transitional character and incompatible-element concentrations several times greater than MORB. These 
results were confirmed by later surveys (Aumento et al., 1971). Though this segment of ridge crest is somewhat shallower than normal mid-ocean ridges, it is still at essentially oceanic depths, and shows no topographic anomaly comparable to that of Iceland or the Azores.

The transition between Icelandic lavas and MORB-type ocean-ridge lavas must, it was reasoned, take place along the Reykjanes Ridge, since Nicholls, Nalwalk, and Hays (1964) had reported basalt with normal MORB major elements just south of the Charlie-Gibbs fracture zone. J.-G. Schilling set out to investigate this transition by dredging systematically southwest along the crest of the Reykjanes Ridge away from Iceland. This operation has been reported in several papers (Schilling, 1973; Hart, Schilling, and Powell, 1973; Sun et al., 1975; Hermes and Schilling, 1976), where the geochemical results have been interpreted in terms of a two-source model. One source would be of lavas enriched in incompatible elements, underneath Iceland (the Icelandic plume); and one a source of MORB-type basalts somewhere to the southwest along the Reykjanes Ridges. In between would be a zone of mixing, in which the product of one source is progressively diluted with the product of the other. Clearly, this model is strongly influenced by the hot-spot ideas of Wilson (1965), as developed by Morgan (1971), Vogt (1974), and others. Following this hypothesis, islands like Hawaii and Iceland must originate from melting in a vertically moving plume of mantle rising from (and fixed relative to) the mesosphere. If this material is at one end of the gradient, then an equally discrete source of MORB-type basalt must exist at the other, and the two must run along the ridge crest to mix.

This simple plume model has been criticized from several directions, and alternative explanations have been suggested (O'Hara, 1973, 1977; O'Nions and Pankhurst, 1974; Flower et al., 1975; Varet and Treuil, 1973), but the original model has proved very resilient. In the course of time it has been modified to allow variation in plume activity through time, channeling of magmas in the mixing zone, and so forth, principally to explain variability of lava composition at one place at much the same time (Schilling and Noe-Nygaard, 1974; Schilling, 1976). Recently, detailed analytical work on Iceland (Wood, 1976) has shown the same to be true there too, so that lavas ranging from depleted in incompatible elements to enriched in incompatible elements can be found erupting over the last million years close together on the Reykjanes Peninsula, from which the Reykjanes Ridge runs.

The other main strand we wish to pursue is that of mantle inhomogeneity. Until the late 1960's, it was usual to regard the mantle as homogeneous, in the absence of evidence to the contrary. Since then, observations have accumulated to suggest that the mantle is in places markedly inhomogeneous, and that this may be important in basalt genesis. Varne and Graham (1971) described hornblende-bearing peridotite xenoliths in alkali basalt from Ataq, S. Yemen, in which abundances of incompatible elements are quite distinct from those of more usual types of peridotite nodules. Frey and Green (1974) extended this in a detailed examination of a suite of nodules from Victoria in Australia. They were able to demonstrate that these were derived from a mantle source where the trace elements varied together in a systematic way. The nodules used in this work, however, came from subcontinental mantle, where the processes leading to geochemical inhomogeneity may be different from those operating beneath the oceans, so it is possible that the results are not directly applicable to Leg 49 basalts.

An alternative approach to mantle inhomogeneity is through analysis of basalts, produced by melting of the mantle. Trace-element analyses of igneous rock series related by crystal fractionation have allowed identification of some elements for which the bulk solid-liquid partition coefficient is very close to zero (Barberi et al., 1975, Weaver et al., 1972). Varet and Treuil (1973) term such elements hygromagmatophile, a term intended to convey not simple rejection by solid phases, but positive acceptance by the liquid. Measurements of basalt compositions show that ratios of hygromagmatophile elements vary from place to place. To change such ratios significantly by crystal fractionation or by events involving large degrees of partial melting would require an unrealistic degree of precipitation, or an unrealistic variation in the proportion of partial melting (Varet and Treuil, 1973). Thus, significant variation in hygromagmatophile-element ratios implies variation in mantle composition before the basalt melting event. Such variation might be primary, or it might be generated in the mantle by some process involving a very small degree of partial melting, such as migration of an interstitial melt through the mantle. Very small degrees of partial melting enable hygromagmatophile-element ratios to be changed effectively, and the result would be a mantle inhomogeneous with respect both to the abundances and ratios of hygromagmatophile-elements.

From both these lines of evidence, there is now very good evidence for the existence of mantle heterogeneity, and it is now important to ask whether this effect is related to the origin of the different magmas erupting along spreading centers. In turn, we shall ask whether observations of oceanic crustal materials can indicate anything about the evolution of mantle heterogeneity and its scale in space and time. We believe that the results of Leg 49 have an important bearing on these questions.

\section{LEG 49 IMPLICATIONS FOR MANTLE HETEROGENEITY}

Full sets of analytical data for the Leg 49 rocks appear in the papers in other chapters in this volume, sometimes as appendices. In these papers, the variations within individual holes and among groups of holes are discussed from the viewpoint of varying degrees of partial melting and subsequent crystal fractionation. Though we do not always agree precisely on interpretation of the data, we do agree that much, though not all of the within-hole variation can be explained by such processes operating on an upper mantle that is homogeneous on a small scale. Some of the within-hole variation and much of the between-hole variation demands, however that on a larger scale the mantle is heterogeneous chemically. In this section we shall extract, from the full sets of data given in the papers of this volume, the measurements most important for examining mantle heterogeneity. It is useful to note here that many of the geochemical analyses were made by different 
laboratories on splits of the same powdered sample, or on chips taken directly adjacent to one another in the core. This allows a high degree of cross-correlation between the measurements reported in the different papers, and allows data for different elements analyzed in separate laboratories to be directly compared on inter-element plots.

Since we want to discuss temporal as well as spatial variation in mantle composition, we need to compare old, and thus relatively altered basalts with very recent, less altered rocks. This can only be done using immobile elements, elements that are little affected by alteration processes, which are also good petrogenetic indicators. Several studies of this problem (Cann, 1970; Pearce and Cann, 1973; Wood et al., 1976; Floyd and Winchester, 1975) suggest that the elements least affected by alteration are those with high formal ionic changes, such as $\mathrm{Ti}, \mathrm{Zr}$, $\mathrm{Nb}, \mathrm{Ta}, \mathrm{Hf}$, and $\mathrm{P}$. These elements seem to form very stable and very insoluble complex oxy-anions. Formally trivalent elements, such as the rare earths and yttrium, are not as immobile. In particular, the light rare earths show distinctly greater mobility than the heavy rare earths. Under conditions of alteration as mild as those that have affected most of the rocks drilled on Leg 49, however, all these elements can be considered immobile, especially where the differences observed are as great as here. On the other hand $\mathrm{K}, \mathrm{Rb}, \mathrm{Sr}$, and $\mathrm{Ba}$ cannot be regarded as immobile (Floyd and Tarney, this volume), and it is much more difficult to make deductions about their variation. Significant mobility shows up as a blurring of inter-element relationships, especially when a more mobile and a less mobile element are compared. No significant blurring can be seen in the data used in this paper.

We start by considering the variations within individual holes, evident on plots of Ce against Y (Figure 2) and Ta against $\mathrm{Tb}$ (Figure 3). Of these elements, one of each pair $(\mathrm{Ce}, \mathrm{Ta})$ is hygromagmatophile, and the other $(\mathrm{Y}, \mathrm{Tb})$ is incompatible but not hygromagmatophile. Ratios between such pairs of elements vary markedly within single holes of Leg 49. This is particularly apparent in Holes 407, 410, and 413, but is also significant in Holes 409 and 411. The major-element and compatible trace-element $(\mathrm{Sc}, \mathrm{Cr}, \mathrm{Co}$, and $\mathrm{Ni}$ ) results quoted elsewhere in this volume (Wood et al.; Tarney et al.) are not consistent with the production of such changes by crystal fractionation from a single parent magma.

O'Hara (1977) has recently invoked open-system magma chamber processes to provide the sort of variation in incompatible-element ratios seen here, and Pearce and Flower (1977) have applied his ideas to magmas from spreading centers. We believe that this effect accounts for some of the geochemical variation in the lavas of these holes, and that it is crucial to a proper understanding of basalt petrogenesis; but we are not convinced that the magnitude of the effects readily producible by this means is great enough.

As discussed elsewhere in this volume, variation in the degree of partial melting is an effective way of changing ratios between pairs of incompatible elements. Tarney et al. (this volume) argue that this effect may be responsible for some of the variation between rocks in individual holes; Wood et al. (this volume) suggest that details of the

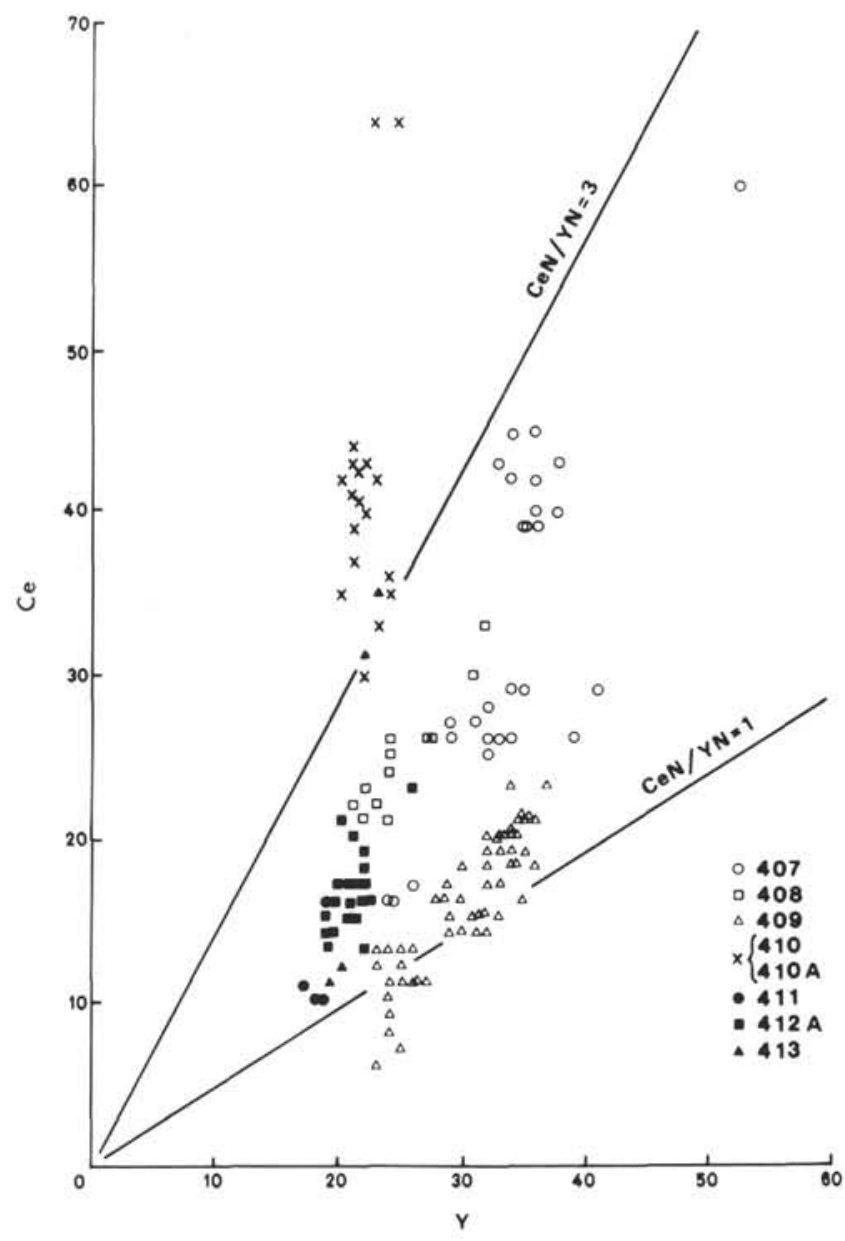

Figure 2. Ce against $Y$ for all Leg 49 sites (from Tarney et al., this volume). The dashed line corresponds to the chondritic ratio of $\mathrm{Ce}$ to $Y$, the ratio of a flat rare-earth pattern. Analysis is by X-ray fluorescence.

relationships between these pairs of elements may not be consistent with the theoretical pattern expected from variation in the degree of partial melting. The variation in strontium isotope ratios within single holes, especially in Hole 407 (Wood et al., this volume) shows that, if variation in degree of partial melting is important, simple bulk partial melting cannot operate, and some such variant as dynamic melting (Hanson, 1977) is required. In addition, the range in degree of partial melting necessary to explain the very wide variation in individual holes is too great to be physically plausible, and would have to range down to such low percentages that it is doubtful whether the magma could be separated from the parent rock. Furthermore, all the basalts drilled on this cruise were produced by spreading at mid-ocean ridges of very similar spreading rate (between 1 and $2 \mathrm{~cm}$ per year). It would be very strange if radically contrasted processes of magma generation could occur in such a constant physical environment. Yet, in this sample of basalts, $\mathrm{Ce} / \mathrm{Y}$ varies by a factor of 8 . So great a variation in a ratio not particularly susceptible to change must be inherited from some pre-magmatic process.

The best explanation for much of the variation shown in Figures 2 and 3 is, then, that the mantle source is 


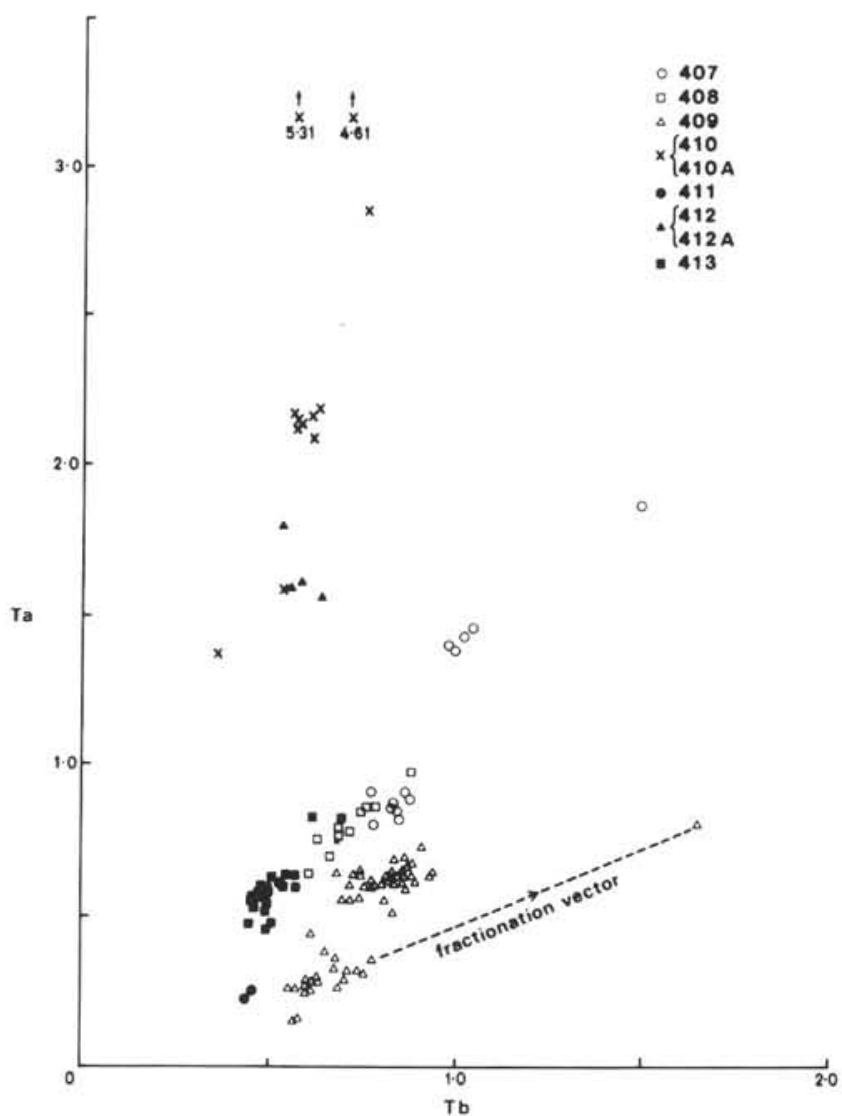

Figure 3. Ta against $\mathrm{Tb}$ for all Leg 49 sites (from Wood et al., this volume). Analysis is by neutron activation.

inhomogeneous from place to place, and that inhomogeneities are on such a small scale that they show up in the basalts from a single site, just as on shore in Iceland (Wood, 1976). This inhomogeneity cannot be interpreted simply in terms of a two-component mixing model, as Langmuir et al. (in press) have shown - a conclusion reinforced by the analyses of Leg 49 . The next section gives further grounds for suggesting that the simple two-component mixing model is not applicable over the whole North Atlantic region.

We examine now the mantle inhomogeneity on a between-hole scale. This is best shown by plots of pairs of incompatible elements, of which both have bulk solid-liquid partition coefficients very much less than 1 . Figures 4 and 5 are two such plots, of $\mathrm{Hf}$ against $\mathrm{Th}$, and of $\mathrm{Zr}$ against $\mathrm{Nb}$. All of these are thoroughly incompatible, but of the pairs, the bulk solid-liquid partition coefficient of Hf is slightly greater than that of $\mathrm{Th}$, and that of $\mathrm{Zr}$ slightly greater than that of $\mathrm{Nb}$. These figures show a different feature from Figures 2 and 3.

In Figures 2 and 3, there is a considerable overlap of site with site, especially since $\mathrm{Ce} / \mathrm{Y}$ and $\mathrm{Ta} / \mathrm{Tb}$ vary considerably within several holes. Figure 4 shows a variation in $\mathrm{Hf} / \mathrm{Th}$ by about a factor of 20, and Figure 5 a similar variation in $\mathrm{Zr} / \mathrm{Nb}$, but the variation between sites (or, rather, geographical areas) is much greater than the within-site variation. Thus, the basalts from the Reykjanes Ridge sites lie along a narrow linear band, those from the

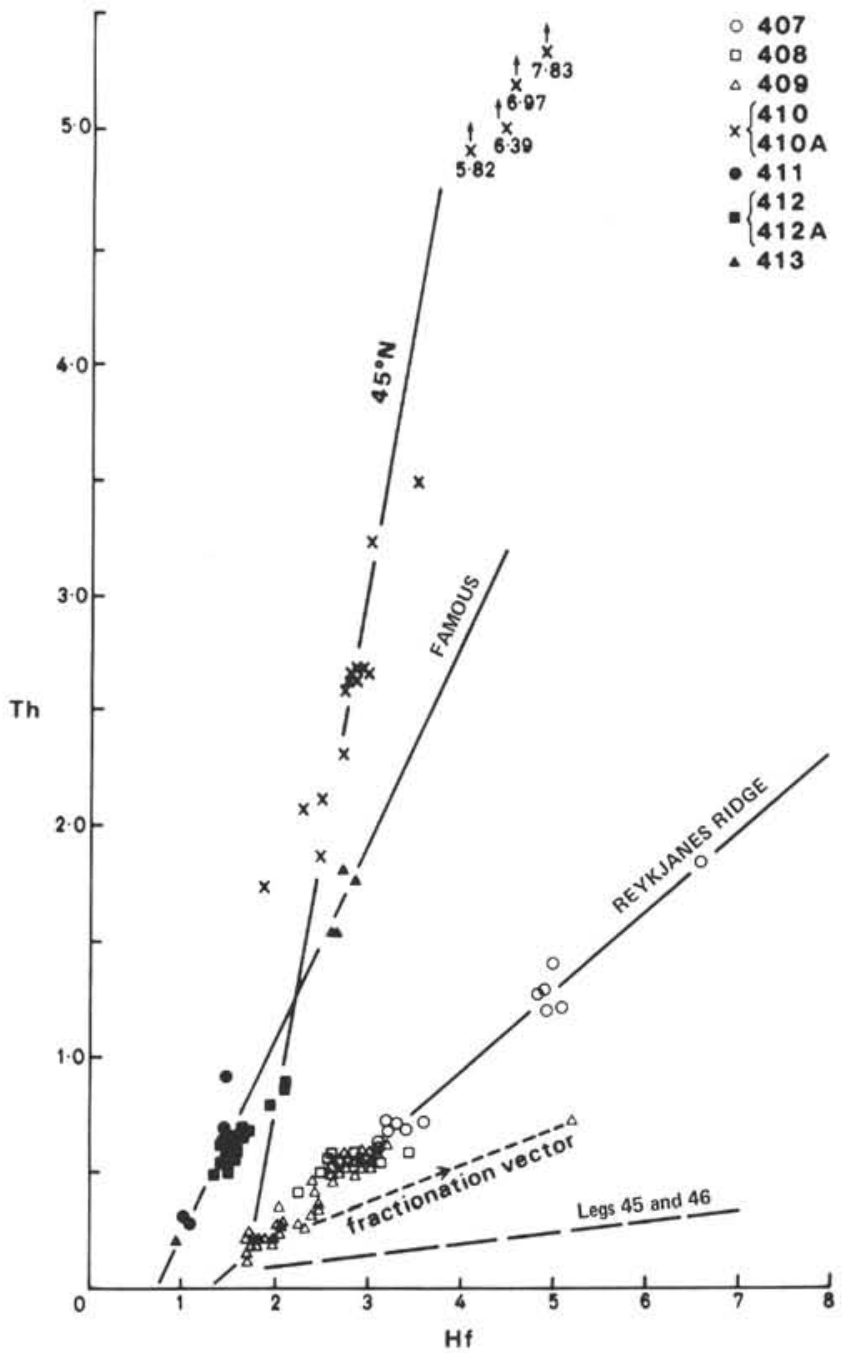

Figure 4. Hf against Th for all Leg 49 sites (from Wood et al., this volume). Analysis is by neutron activation.

FAMOUS area along another, and those from $45^{\circ} \mathrm{N}$ along yet another. The dashed line on Figure 4 shows the Hf/Th relationship for the basalts from Legs 45 and 46 (Bougault et al., 1978). Figure 5 includes data from Erlank and Kable (1976), collected on dredged samples from $45^{\circ} \mathrm{N}$, which help to define the band for that region more closely. Many of the bands cannot be projected to pass through the origin of the graphs. For these bands, the $\mathrm{Hf} / \mathrm{Th}$ and $\mathrm{Zr} / \mathrm{Nb}$ ratios vary along the length of the band. Individual crystal fractionation trends run at constant $\mathrm{Hf} / \mathrm{Th}$ and $\mathrm{Zr} / \mathrm{Nb}$, as shown by the vector linking the highly fractionated lava at Site 409 with the surrounding less fractionated rocks on Figures 4 and 5 . These fractionation trends therefore run at an angle to the band axis, and thus most of the variation within each band cannot correspond to crystal fractionation; it must represent some subsidiary inhomogeneity in the mantle instead. This conclusion is reinforced by the fine structure of the bands; closer inspection reveals that each band shows a distinct fine structure corresponding to the within-hole and within-area variation in the $\mathrm{Ce} / \mathrm{Y}$ and $\mathrm{Ta} / \mathrm{Tb}$ relationships of Figures 2 and 3 . The most important variation of Figures 3 and 4, however, is that between areas, 


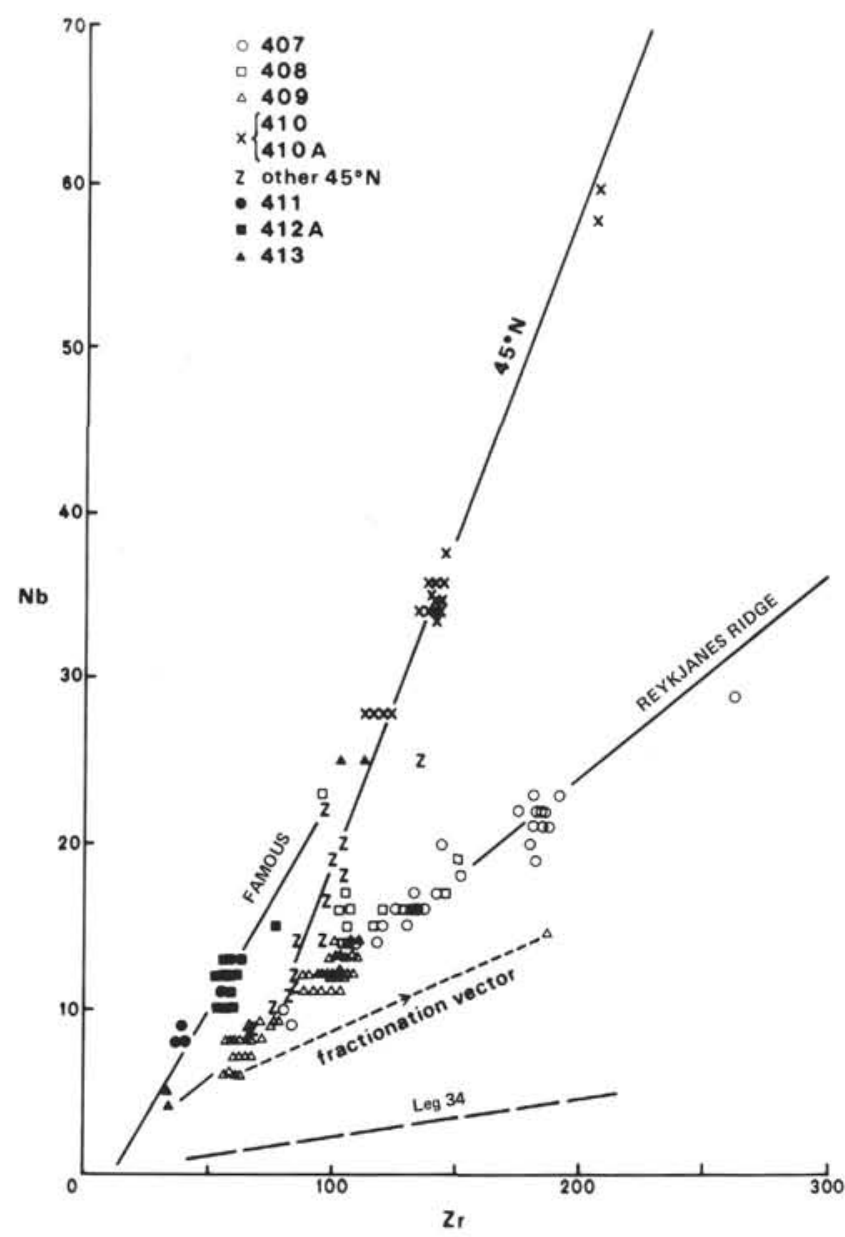

Figure 5. Zr against $\mathrm{Nb}$ for all Leg 49 sites (from Tarney et al., this volume). Analysis is by X-ray fluorescence.

and this must be an effect of mantle heterogeneity, if only because the magnitude of the differences in hygromagmatophile-element ratios is far too great from area to area to be explained by processes acting during the basalt melting event. The regularity of the process can be seen by comparing Figures 4 and 5, involving two quite different pairs of elements. In each plot there is an exactly equivalent grouping into three bands corresponding to the three broad geographical areas, and the relative order of slopes on each graph is the same, too.

This kind of variation is clearly more fundamental than that of Figures 2 and 3. The consistency of the Hf/Th and $\mathrm{Zr} / \mathrm{Nb}$ relationships within a particular area, and the contrasts between areas, suggest that this characteristic is one superimposed regionally on the mantle, and one that can be used to map areas within which the mantle will have broadly the same characteristics. Figures 4 and 5 show that the variation from place to place must be considerable, and also that, at any one place, the general character of the mantle must persist for long periods of time. On the Reykjanes Ridge, the analyses of all three sites fall into one band on both figures, even though they are separated in age by about 35 million years and in space by $300 \mathrm{~km}$. In between the formation of the crust at Site 407 and that at Site 409 , a very large amount of mantle must have been partially melted at that point on the ridge crest to produce the intervening crust. Yet all of that mantle must have had a consistency of composition with respect to these element ratios on a broad scale throughout that time. We will take up this point again in the next section.

Such marked variation in element ratios does not occur for all pairs of incompatible elements. The Ti- $\mathrm{Zr}$ ratio, for example, is close to 100 for all the basalts analyzed except those at Site 410 , where crystallization of a Ti-rich phase seems probable. Whatever process disturbed $\mathrm{Hf} / \mathrm{Th}$ and $\mathrm{Zr} / \mathrm{Nb}$ does not seem to have affected $\mathrm{Ti} / \mathrm{Zr}$. Other pairs of elements that do not show such a disturbance include $\mathrm{Ti} / \mathrm{P}$, $\mathrm{La} / \mathrm{Ta}$, and $\mathrm{Ta} / \mathrm{Nb}$. Such lack of disturbance probably results from very similar bulk solid-liquid partition coefficients under mantle conditions for the pairs of elements concerned.

Finally, in this section, we discuss a stratigraphy of mobility events. Comparison of Figures 2 and 3 with Figures 4 and 5 suggests strongly that the event that produced the $\mathrm{Hf} / \mathrm{Th}$ and $\mathrm{Zr} / \mathrm{Nb}$ bands preceded the event that gave the structure on the $\mathrm{Ce} / \mathrm{Y}$ and $\mathrm{Ta} / \mathrm{Tb}$ diagrams. This is confirmed by the presence of a fine structure to the $\mathrm{Hf} / \mathrm{Th}$ and $\mathrm{Zr} / \mathrm{Nb}$ bands corresponding to the $\mathrm{Ce} / \mathrm{Y}$ and $\mathrm{Ta} / \mathrm{Tb}$ groups. On the other hand, the similarity of Figures 4 and 5 suggests that the $\mathrm{Hf} / \mathrm{Th}$ banding and the $\mathrm{Zr} / \mathrm{Nb}$ banding were produced at the same time by the same process. It seems that by this means we can so far distinguish two such stratigraphically related events. The earlier one produced major regional trace-element inhomogeneities in an initially homogeneous mantle (see Figures 4 and 5). The later one gave rise to a fine structure within the bands of Figures 4 and 5 and to the major groupings of Figures 1 and 2. This later event may have been associated with the basalt melting event, or may have preceded this event.

Absolute dating of these events is not possible yet, but the recent description of pseudo-isochrons from related volcanic rocks (Brooks et al., 1976) suggests that this may be possible eventually. The later event will be datable directly by Nd-Sm pseudo-isochrons, since it shows up as a disturbance of rare-earth relationships. The earlier event might be datable by $\mathrm{Rb}-\mathrm{Sr}$ pseudo-isochrons, but this cannot be certain, because of mobility of both elements (especially $\mathrm{Rb}$ ) under sea-floor alteration (Floyd and Tarney, this volume). The disturbance of $\mathrm{Hf} / \mathrm{Th}$ ratios by this event suggests, however, that lead isotope pseudo-isochrons may be more directly applicable.

\section{GEOGRAPHIC DISTRIBUTION OF MANTLE HETEROGENEITY}

Besides the analyses from Leg 49, other analyses are available from a number of sites in the North Atlantic. Sometimes these are of single samples, and often do not contain values for the incompatible, less mobile elements used in the previous discussion. But the available analyses do suggest a pattern of variation throughout the North Atlantic which has some bearing on the problem of mantle heterogeneity. Because of the origin of the Atlantic crust by ocean-floor spreading, variation in chemistry away from the ridge crests gives some information about varying mantle composition with time. This is complicated by the difficulty 
of knowing precisely in which direction the appropriate flow lines run from each point on the ridge crest, even if it was clear which were the appropriate flow lines to use. Neither crustal nor mesospheric flow lines seem entirely appropriate to a problem essentially concerned with the asthenosphere. A broad pattern certainly emerges, however.

$\mathrm{The} \mathrm{Ce} / \mathrm{Y}$ and $\mathrm{Ta} / \mathrm{Tb}$ relationships, and thus the shape of the rare-earth patterns, can vary on an extremely small geographic scale. In several individual holes, marked variations in these relationships occur, suggesting that if it is caused by mantle heterogeneity, the mantle is variable on the scale of a few kilometers or less.

This variation is summarized schematically in Figure 6, where the geochemical characteristics of the drilled lavas are abstracted into two dimensions: a degree of evolution in terms of major elements, and a degree of hygromagmatophile enrichment, as shown schematically by the slope of the rare-earth patterns. Some of this variation may be related to processes associated with melting, and may have been induced on a less heterogeneous source during melting, segregation, or mixing of batches of melt (Wood et al., this volume; Tarney et al., this volume). Clear-cut understanding of this variation will be possible only with more detailed surveying.

The variation in $\mathrm{Hf} / \mathrm{Th}$ and $\mathrm{Zr} / \mathrm{Nb}$ relationships is on a much broader geographic scale. All the Reykjanes Ridge sites show a distinctive relationship which is very different from that at $45^{\circ} \mathrm{N}$ and in FAMOUS. At $45^{\circ} \mathrm{N}$, the analyses of Leg 49 can be supplemented by analyses from Cann (1970) and Erlank and Kable (1976) on dredged material. Here again, a characteristic relationship covers the whole region. In the FAMOUS area, most of the available data also show a single consistent relationship, including analyses from Leg 49 (this volume), most of those from Leg 37 (Lambert and Holland, 1977), and unpublished analyses of dredged material from the flanks of the median valley (R.A. Heath, personal communication). The latter two groups of analyses are most complete for $\mathrm{Zr} / \mathrm{Nb}$.

Since each of these relationships is consistent within an area but different between areas, this must reflect a consistency in mantle composition on the scale of hundreds of kilometers in space and tens of millions of years in time, but contrasting on a larger scale, say $1000 \mathrm{~km}$ or so in space.

Two points from the FAMOUS results illuminate this picture. One comes from the results of analysis from Hole 413. Within this hole are two geochemical units, both of them with rather magnesian and $\mathrm{Ni}$ - and $\mathrm{Cr}$-rich compositions, and thus relatively unevolved. One of these units, the upper, contains the highest values for hygromagmatophile elements yet reported from the FAMOUS area, and the other contains some of the lowest

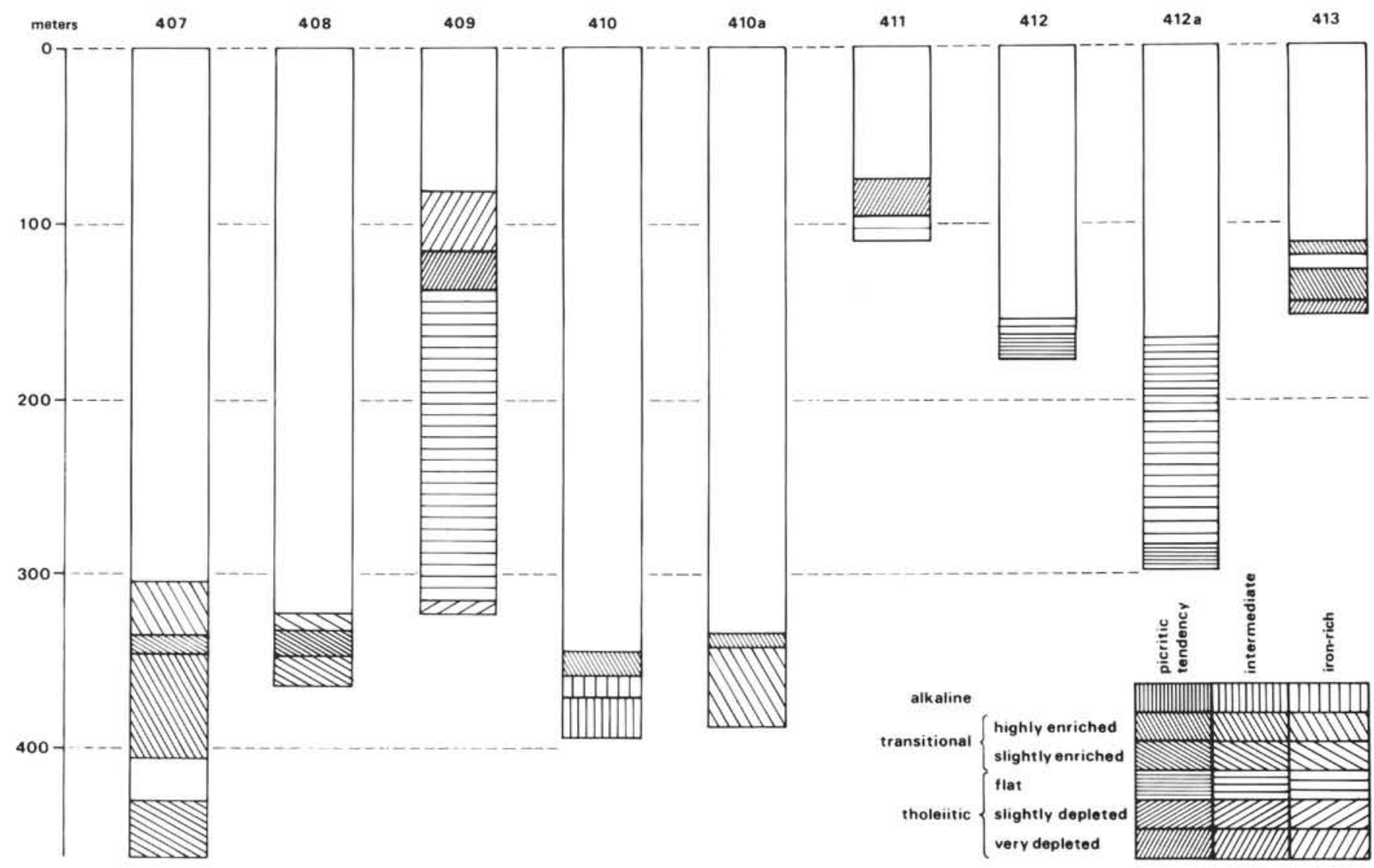

Figure 6. Geochemical summary diagram of the drilled basalts from Leg 49, dividing the geochemical units recognized by their degree of evolution, and their geochemical character as shown schematically as an exaggerated scope to a rare-earth pattern. 
values for these elements. Both units fall within the band for the FAMOUS area for both $\mathrm{Zr} / \mathrm{Nb}$ and $\mathrm{Hf} / \mathrm{Th}$, one at one end, the other at the other. The similarity of major-element compositions shows that this cannot be a crystal fractionation relationship. It is unlikely to be an effect of variable degree of melting during production of basalt (Wood et al., this volume), since the band forms a linear array, rather than the curved one expected from variable partial melting (Varet and Treuil, 1973). It seems to represent, rather, mantle inhomogeneity within the band, where mantle compositions range from depleted in hygromagmatophile elements to enriched. Both extremes seem to be available within the area that can supply flows to Site 413.

The other point concerns Hole 335 , the $\mathrm{Zr} / \mathrm{Nb}$ points from which seem to lie significantly away from the FAMOUS band as defined by the other analyses (Lambert and Holland, 1977). The mean values of $\mathrm{Zr}$ and $\mathrm{Nb}$ in this hole (composed of rather uniform basalts) are 57 and 4 , respectively. To bring this mean within the FAMOUS band would require doubling or tripling of the $\mathrm{Nb}$ content at this $\mathrm{Zr}$ value. Site 335 is on crust $16.5 \mathrm{~m} . \mathrm{y}$. old (Aumento, 1977), about $190 \mathrm{~km}$ from the median valley, and is the oldest site drilled in this region. It seems that, in passing from Site 334 ( 8.9 m.y.) to Site 335, a boundary has been crossed between two mantle regions with rather different $\mathrm{Zr} / \mathrm{Nb}$ relationships. This information, scanty though it is, indicates the size of a mantle unit giving a constant band relationship, and the abruptness of its boundary.

Thus, bodies of mantle several hundred kilometers across are suggested, relatively uniform internally in the relationship between hygromagmatophile elements, but containing on a much smaller scale rapid transitions between mantle relatively depleted in hygromagmatophiles and mantle relatively enriched.

On a broader scale, the North Atlantic region may be compared with other nearby areas of ocean. $\mathrm{Zr} / \mathrm{Nb}$ ratios in Leg 49 basalts range from 4 to 12 in FAMOUS sites and at $45^{\circ} \mathrm{N}$, and run somewhat higher (7 to 15 ) in the Reykjanes Ridge sites. Similar values pertain to other areas of the North Atlantic. At Palmer Ridge $\left(43^{\circ} \mathrm{N}, 20^{\circ} \mathrm{W}\right.$, Figure 1), where the crust is $60 \mathrm{~m} . \mathrm{y}$. old, $\mathrm{Zr} / \mathrm{Nb}$ ranges about 7 (R.A. Heath, personal communication), and at Swallow Bank $\left(41^{1 / 2}{ }^{\circ} \mathrm{N}, 14 \frac{1}{2}{ }^{\circ} \mathrm{W}\right.$, Figure 1), 85 -m.y.-old crust gives ratios of about 8. Preliminary analysis of some Icelandic samples from the Reykjanes Peninsula gives ratios of 10; for the DSDP sites in the Norwegian Sea drilled on Leg 38 , Raschka and Eckhardt (1976) report values generally between 6 and 10 as far north as the most northerly site drilled (344), at $76^{\circ} \mathrm{N}$ on the Knipovich Ridge.

Many basalts from the oceans outside the North Atlantic show very different $\mathrm{Zr} / \mathrm{Rb}$ ratios. Basalts from dredge hauls at $30^{\circ} \mathrm{N}$ and $26^{\circ} \mathrm{N}$ on the Mid-Atlantic Ridge give ratios ranging from 25 to 50 (Erlank and Kable, 1976; R.A. Heath, personal communication). The DSDP Leg 34 basalts from the Nazca plate (Cann and Heath, 1976) give ratios between 30 and 40, as do dredged lavas from the Indian Ocean (Cann, 1970). Erlank and Kable (1976) report one sample from the South Atlantic with a $\mathrm{Zr} / \mathrm{Nb}$ ratio over 100 . Clearly, mantle with much higher $\mathrm{Zr} / \mathrm{Nb}$ than normal in the Atlantic north of $36^{\circ} \mathrm{N}$ is widely available. Some samples from the South Atlantic (Erlank and Kable, 1976) and from the Gulf of Aden (Cann, 1970) show values much closer to those measured on the Leg 49 rocks.

With the information presently available, then, the picture is one where all of the North Atlantic north of $36^{\circ} \mathrm{N}$, and the Norwegian Sea to $76^{\circ} \mathrm{N}$, give $\mathrm{Zr} / \mathrm{Nb}$ ratios consistently low relative to samples from many other parts of the world's oceans. The boundaries of this broad North Atlantic province are not clearly defined, nor is it known how sharp the transition is. At the ridge crest, it occurs between $30^{\circ}$ and $37^{\circ} \mathrm{N}$, but how it runs away from the ridge crest is unknown and clearly needs urgent investigation. Within this broad province, variation in mantle composition occurs on a variety of scales, ranging from the scale of hundreds of kilometers, represented by the marked variation between groups of sites, to small-scale fluctuations on the order of kilometers, as in the rocks of individual holes. Again, the structure of the transitions between such regions is unknown. Investigation of them would throw much clearer light on the processes responsible for this heterogeneity.

\section{CONCLUSIONS}

Many of the geochemical measurements on the Leg 49 rocks are best interpreted in terms of heterogeneity of mantle composition on a variety of scales.

The structure of the $\mathrm{Ce} / \mathrm{Y}$ and $\mathrm{Ta} / \mathrm{Tb}$ graphs (Figures 1 and 2) represents a local scale of variation which is present to some extent in most holes drilled. Some of this variability may be related to processes of basalt generation, but much is likely to be primary variability in the mantle source, especially that in Holes 413 and 407 . This variation must reflect fluctuations in mantle composition on a scale of a few (less than 10) kilometers.

The main structure of the $\mathrm{Hf} / \mathrm{Th}$ and $\mathrm{Zr} / \mathrm{Nb}$ graphs (Figures 4 and 5) is on a broader geographic scale. Areas several hundred kilometers across, formed through several tens of millions of years at one stretch of ridge crest, show very consistent linearly banded relationships on such graphs, distinct from the banded relationships in other neighboring areas. The bands do not necessarily project through the origin on these graphs, so that inter-element ratios may change along the band length, though slopes of bands are all positive. The variation within any one band cannot in general be related to crystal fractionation, and seems to reflect the same processes as those producing the structure on the $\mathrm{Ce} / \mathrm{Y}$ and $\mathrm{Ta} / \mathrm{Tb}$ graphs, or at any rate similar ones. The nature of the transition between two areas characterized by different band relationships would be important to examine. There is some indication that such a transition occurred in the FAMOUS area between formation of the crust at Site 335 and formation of that at Site 334 .

On a still broader scale, the whole of the North Atlantic north of $36^{\circ} \mathrm{N}$ is a region where $\mathrm{Zr} / \mathrm{Nb}$ ratios are lower than in much of the rest of the world's oceans. This region must have been fed by asthenosphere rising and melting at the Mid-Atlantic Ridge and having such low ratios relative to the asthenosphere tapped elsewhere by ocean-floor spreading. The reason behind such broad variation in geochemistry is still obscure. It may be related to the previous melting history of that piece of mantle, or to some 
regional enrichment in certain incompatible traces. The transition between the area supplied by mantle of one type and that of the other occurs at the Mid-Atlantic Ridge crest between $30^{\circ} \mathrm{N}$, where the Atlantis dredgings recovered lava with high $\mathrm{Zr} / \mathrm{Nb}$ ratios, and the FAMOUS area at $36^{\circ} \mathrm{N}$.

The changing inter-element relationships on different geographic scales can be given a chronological framework, in that smaller scale heterogeneities are clearly superimposed on heterogeneities of larger geographic scale, and so must post-date them. Generation of the regionally low $\mathrm{Zr} / \mathrm{Nb}$ ratios for the North Atlantic must pre-date generation of the band structure of Figures 4 and 5, which must in turn pre-date generation of the variation within individual holes. At each scale, the effects of inhomogeneities are evident with different elements, as though different elements had been mobile to a greater or lesser extent at different times. We do not believe that the scales of variation we have identified necessarily represent discrete mobility events; we prefer a model in which the scale of mixing in the asthenosphere has been gradually reduced with time, thus generating heterogeneities on a wide variety of scales. Dating of this increase in inhomogeneity with time can be achieved by application of pseudo-isochron studies (Brooks et al., 1976), where the nearly concordant pseudo-isochron ages of 1.6 and $1.8 \times$ $10^{9}$ years reported for $\mathrm{Rb} / \mathrm{Sr}$ and $\mathrm{U} / \mathrm{Pb}$ systems in oceanic environments may represent a time related to the generation of some of the larger scale inhomogeneities. We feel that our smallest scale heterogeneities, on the other hand, may still be forming now.

Finally, we should emphasize our agreement with Frey and Green (1974), Lloyd and Bailey (1975), and other workers, that such inhomogeneities are probably generated by migration within the mantle of small amounts of interstitial fluid, probably rich in water and carbon dioxide. The place where this is likely to be most active, and where heterogeneity is developing now, is in the asthenosphere.

\section{ACKNOWLEDGMENTS}

We would like gratefully to acknowledge the help of the following people who provided analytical data on which this synthesis has been based: H. Bougault, O. Corre, J.L. Joron, M. Treuil, H. Bizouard, M.J. Norry, C.J. Hawkesworth, J.C. Roddick, A.D. Saunders, S.D. Weaver, N.C.B. Donnellan, G.L. Hendry, and R.A. Heath.

We are grateful, in addition, to the other members of the shipboard party for discussions that helped us to clarify our ideas.

\section{REFERENCES}

Aumento, F., 1977. Deep drill-1974, Can. J. Earth Sci., v. 14, p. 651-655.

Aumento, F., Loncarevic, B.D. and Ross, D.I., 1971. Hudson Geotraverse: geology of the Mid-Atlantic Ridge at $45^{\circ} \mathrm{N}$, Phil. Trans Roy. Soc. London, ser. A., v. 268, p. 623-650.

Barberi, F., Ferrara, G., Santacroce, R., Treuil, M., and Varet, J., 1975. A transitional basalt-pantellerite sequence of fractional crystallization, the Boina centre (Afar rift, Ethiopia), J. Petrol., v. 16, p. 22-56.

Bougault, H., Treuil, M., and Joron, J.L., 1978. Trace elements in basalts from $22^{\circ} \mathrm{N}$ and $36^{\circ} \mathrm{N}$ in the Atlantic Ocean: Fractional crystallization, partial melting, and heterogeneity of the upper mantle. In Melson, W.G., Rabinowitz, P.D., et al., Initial
Reports of the Deep Sea Drilling Project, v. 45: Washington (U.S. Government Printing Office).

Brooks, C.K., Hart, S.R., Hofmann, A., and James, D.E., 1976. $\mathrm{Rb}-\mathrm{Sr}$ mantle isochrons from oceanic regions. Earth Planet. Sci. Lett., v. 32, p. 51-61.

Cann, J.R., 1970. Rb, Sr, Y, $\mathrm{Zr}$ and $\mathrm{Nb}$ in some ocean floor basaltic rocks, Earth Planet. Sci. Lett., v. 10, p. 7-11.

Cann, J.R. and Heath, R., 1976. Some trace elements in basalts from Leg 34. In Yeats, R.S., Hart, S.R., et al., Initial Reports of the Deep Sea Drilling Project, v. 34: Washington (U.S. Government Printing Office), p. 289-292.

Cann, J.R. and Simkin, T., 1971. A bibliography of ocean-floor rocks. Phil. Trans Roy. Soc. London, ser. A, v. 268, p. 737-743.

Engel, A.E.J., Engel, C.G. and Havens, R., 1965. Chemical characteristics of oceanic basalts and the upper mantle, Geol. Soc. Am. Bull., v. 76, p. 719-734.

Erlank, A.J. and Kable, E.J.D., 1976. The significance of imcompatible elements in Mid-Atlantic Ridge basalts from $45^{\circ} \mathrm{N}$ with particular reference to $\mathrm{Zr} / \mathrm{Nb}$, Contrib. Mineral. Petrol., v. 54, p. 281-291.

Ewart, A. and Bryan, W.B., 1972. Petrography and geochemistry of the igneous rocks from Eua, Tongan Islands, Geol. Soc. Am. Bull., v. 83 , p. $3281-3298$.

Flower, M.F.J., Schmincke, H.U., and Thompson, R.N., 1975. Phlogopite stability and the ${ }^{87} \mathrm{Sr} /{ }^{86} \mathrm{Sr}$ step in basalts along the Reykjanes Ridge, Nature, v. 254, p. 404-406.

Floyd, P.A. and Winchester, J.A., 1975. Magma type and tectonic setting discrimination using immobile elements, Earth Planet. Sci. Lett., v. 27, p. 211-218.

Frey, F.A. and Green, D.H., 1974. The mineralogy, geochemistry and origin of lherzolite inclusions in Victorian basanites, Geochim. Cosmochim. Acta, v. 38, p. 1023-1059.

Frey, F.A. and Haskin, L.A., 1964. Rare earths in oceanic basalts, J. Geophys. Res., v. 69, p. 775-780.

Gast, P.W., 1965. Terrestrial ratio of potassium to rubidium and the composition of Earth's mantle, Science, v. 147, p. 858-860.

Hanson, G.N., 1977. Geochemical evolution of the suboceanic mantle, J. Geol. Soc. London, v. 134, p. 235-253.

Hart, S.R., Glassley, W.E., and Karig, D.E., 1972. Basalts and sea-floor spreading behind the Mariana island arc, Earth Planet. Sci. Lett., v. 15, p. 12-18.

Hart, S.R., Schilling, J.-G., and Powell, J.L., 1973. Basalts from Iceland and along the Reykjanes ridges: $\mathrm{Sr}$ isotope geochemistry, Nature, v. 246, p. 104-107.

Hermes, O.D. and Schilling, J.-G., 1976. Olivine from Reykjanes Ridge and Iceland tholeiites, and its significance to the two-mantle source model, Earth Planet. Sci. Lett., v. 28, p. 345-355.

Hill, M.N., 1960. A median valley of the Mid-Atlantic Ridge, Deep-Sea Res., v. 6, p. 193-205.

Kay, R., Hubbard, N.J. and Gast, P.W., 1970. Chemical characteristics and origin of oceanic ridge volcanic rocks, $J$. Geophys. Res., v. 75, p. 1585-1613.

Lambert, R. St J. and Holland, J.G., 1977. Trace elements and petrogenesis of DSDP Leg 37 basalts, Canadian J. Earth Sci., v. 14 , p. $809-836$.

Langmuir, C.H., Vocke, R.D., and Hanson, G.N., in press. A general mixing equation: applied to the petrogenesis of basalts from Iceland and the Reykjanes Ridge, Earth Planet. Sci. Lett.

Lloyd, F.E. and Bailey, D.K., 1975. Light element metasomatism of the continental mantle: the evidence and consequences. In Ahrens, L.H., Dawson, J.B., Duncan, A.R., and Erlank, A.J. (Eds.), Physics and chemistry of the earth, v. 9: Oxford (Pergamon), p. 389-416. 
Morgan, W.J., 1971. Convection plumes in the lower mantle, Nature, v. 230 , p. $42-43$.

Muir, I.D. and Tilley, C.E., 1964. Basalts from the northern part of the rift zone of the Mid-Atlantic Ridge, J. Petrol., v. 5, p. 409-434.

, 1966. Basalts from the northern part of the Mid-Atlantic Ridge: II. The Atlantis collections near $30^{\circ} \mathrm{N}, J$. Petrol., v. 7, p. 193-201.

Nicholls, G.D., Nalwalk, A. and Hays, E.E., 1964. Nature and composition of rock samples dredged from Mid-Atlantic Ridge, Mar. Geol., v. 1, p. 333-343.

O'Hara, M.J., 1973. Non-primary magmas and dubious mantle plume beneath Iceland, Nature, v. 243, p. 507-508. , 1977. Geochemical evolution during fractional crystallization of a periodically refilled magma chamber, Nature, v. 266, p. 503-507.

O'Nions, R.K. and Pankhurst, R.J., 1974. Petrogenetic significance of isotope and trace-element variations in volcanic rocks from the Mid-Atlantic, J. Petrol., v. 15, p. 603-634.

Pearce, J.A. and Cann, J.R., 1973. Tectonic setting of basic volcanic rocks determined using trace element analyses, Earth Planet Sci. Lett., v. 19, p. 290-300.

Pearce, J.A. and Flower, M.F.J., 1977. The relative importance of petrogenetic variables in magma genesis at accreting plate margins: a preliminary investigation, J. Geol. Soc. London, v. 134 , p. $103-127$.

Raschka, H. and Eckhardt, F.-J., 1976. Geochemistry of basalts from the Norwegian-Greenland Sea, Leg 38, DSDP. In Talwani, M., Udintsev, G., et al., Initial Reports of the Deep Sea Drilling Project, v. 38: Washington (U.S. Government Printing Office), p. 719-730.

Schilling, J.-G., 1973. Iceland mantle plume: geochemical study of Reykjanes Ridge, Nature, v. 242, p. 565-575. , 1976. Rare-earth, Sc, Cr, Fe, Co and Na abundances in DSDP leg 38 basement basalts: some additional evidence on the evolution of the Thulean volcanic province. In Talwani,
M., Udintsev, G., et al., Initial Reports of the Deep Sea Drilling Project, v. 38: Washington (U.S. Government Printing Office), p. 741-750.

Schilling, J.-G. and Noe-Nygaard, A., 1974. Faroe-Iceland plume: rare-earth evidence, Earth Planet. Sci. Lett., v. 24, p. $1-14$.

Sun, S.-S., Tatsumoto, M., and Schilling, J.-G., 1975. Mantle plume mixing along the Reykjanes Ridge axis: lead isotopic evidence, Science, v. 190, p. 143-147.

Varet, J. and Treuil, M., 1973. Critères pétrologiques, géochimiques et structuraux de la genèse et de la différentiation des magmas basaltiques: exemple de l'Afar, Thesis presented at the Université de Paris-Sud, Centre d'Orsay.

Varne, R. and Graham, A.L., 1971. Rare earth abundances in hornblende and clinopyroxene of a hornblende and clinopyroxene of a hornblende lherzolite xenolith: implications for upper mantle fractionation process, Earth Planet. Sci. Lett., v. 13 , p. $11-18$.

Vogt, P.R., 1974. The Iceland phenomenon: imprints of a hot spot on the ocean crust, and implications for flow below the plates. In Kristjansson, L. (Ed.), Geodynamics of Iceland and the North Atlantic area: Holland (Riedel, Dordrecht), p. 105-126.

Weaver, S.D., Sceal, J.S.C., and Gibson, I.L., 1972. Trace elements data relevant to the origin of trachytic and pantelleritic lavas in the East African rift system, Contrib. Mineral. Petrol., v. 36, p. $181-194$.

Wilson, J.T., 1965. Evidence from ocean islands suggesting movement in the earth, Phil. Trans Roy. Soc. London, ser. A, v. 258 , p. $145-167$.

Wood, D.A., 1976. Spatial and temporal variation in the trace element geochemistry of the eastern Iceland flood basalt succession, J. Geophys. Res., v. 81 , p. $4353-4360$. .

Wood, D.A., Gibson, I.L., and Thompson, R.N., 1976. Elemental mobility during zeolite facies metamorphism of the Tertiary basalts of eastern Iceland, Contrib. Mineral. Petrol., v. 55 , p. 241 . 